Language in Africa 1(3), 2020, 266-291. doi: 10.37892/2686-8946-2020-1-3-266-291

\title{
ADPOSITIONAL EXPRESSION OF SPATIALITY IN ADAMAWA LANGUAGES WITH FOCUS ON THE SAMBA-DURU GROUP
}

\author{
Sabine Littig \\ Johannes Gutenberg-Universität Mainz \\ littig@uni-mainz.de
}

\begin{abstract}
A recurrent topic in language typology are adpositions within a crosslinguistic perspective. This paper questions whether there are similarities in form and function of spatial adpositions in Adamawa languages. Based on data of existing grammars and fieldwork results, form and function of the adpositions in question will be presented and discussed. The main result is that almost all languages show a generic adposition expressing spatial relations in general. First a theoretical overview about formal and functional features of adpositions is presented. This is completed with an excerpt of the relation between spatial marking and noun classes and a short introduction in spatial deixis. The theoretical explanations are followed by an empirical comparative study which attempts to empirically back up the theoretical conclusions and presents the results.
\end{abstract}

Key words: Adamawa, adpositions, spatiality, Samba-Duru

\section{Introduction}

This paper discusses whether there are similarities in form including position and function of adpositions. Thereby I focus on languages of the Samba-Duru group. The data is based on personal research or existing language descriptions. This article discusses the following languages: Kolbila, Samba Leeko, Dii, Pere, Doyayo, Beiya, Riitime and Kobom representing the Samba-Duru group (Kleinewillinghöfer 2011; Littig 2016; 2018), Mundang (Elders 2000) and Nganha (or Mbang) Mbum of the Kebi-Benue group (Elders 2006; Hino 1978; 
Hagège 1970a; $1970 \mathrm{~b}$ ), the Zing dialect of Mumuye (Shimizu 1983), Lwàa (Lua) of the Bua group (Boyeldieu 1985), Fali (Kramer 2014) and Longuda (Vigeland forthcoming) as presented in Table 1 in $\$ 2$. The languages' names are listed referring to their subgroup (head line) of the Adamawa language continuum.

In general, an adposition expresses spatial or temporal relation of one term and a linguistic unit, in some cases semantic relations are expressed as well (DeLancey 2005). Adpositions may derive from nouns, verbs and adverbs (Heine et al. 1991; Hagège 2001; Hopper $\&$ Traugott 2003). Some languages only show a small highly grammaticalized set, whereas others show large sets of elements with "very lexical meanings and functions" (DeLancey 2005: 187). In languages with a smaller set, the adpositions function as markers of core relations and mark adverbial relations (ibd.). Tröbs (1998) classifies terms of adpositional function in Jeli (Mande) according to their degrees of grammaticalization, in formal adpositions, lexical adpositions and complex adpositions. Formal adpositions do not have synchronic relation to the lexicon. Lexical adpositions refer to an expression synchronically existing in the lexicon. Complex adpositions are formed by lexical and formal adpositions. Hopper \& Traugott (2003) distinguish between primary adpositions and secondary adpositions. In correspondence to Tröbs (1998) primary adpositions form a restricted set of monosyllabic forms expressing the grammatical relation of a term and the head of the adpositional phrase (formal adpositions). Secondary adpositions define concrete relations and are developed from a connection of a primary adposition and a relator noun (complex adpositions). In addition, adpositions are classified according to their position to the term they relate to or better the noun phrase they occur with (Dryer 2013). Prepositions precede the noun phrase; postpositions follow the noun phrase (Dryer 2013). Circumpositions are secondary adpositions positioned on both sides of the noun phrase (Reindl 2001). Ambipositions can be either a preposition or a postposition, refer to circumpositions or are words that function as a preposition and postposition simultaneously (Libert 2006). Adpositions also differ considering formal aspects, they 
occur phonologically bound or as free forms. They show morphological features or differ in position (preceding or following the head noun) or are even postposed to a full sentence. Their formal differences will be discussed in the following sections as well. Previous works on Adamawa languages did not focus on adpositions at all. Adpositions were rather marginal or not discussed in the language descriptions of the 1990s. If they were mentioned, they were referred to as "preposition" as a general term as well as "fonctionnels", "indicateur de function", "marker" or "particles" and analyzed as "clitic", "particle", "free position", "affix", "pronoun" or "demonstrative" (Hagège 1970a; 1970b; Wiering \& Wiering 1994; Boyd 1974; Hino 1978; Bonhoff 2010; Bonhoff \& Boyd 2003). Working on adpositions, I realised that spatial constructions were described as such and could therefore be examined better. I therefore concentrate in this survey on adpositions expressing spatial relations.

On the discourse level this contribution deals with spatial deixis. Spatial deixis is defined as "that aspect of deixis which involves referring to the locations in space of the communication act participants" (Fillmore 1982). The discussion of spatial deixis and spatial relations interacts with the question how space is expressed in a given language in general within a frame of reference. A frame of reference represents coordinate systems that involve the conceptual constituents: figure (i.e. the entity to be located), ground (i.e. the reference entity), origin (meeting point of the frame's axes), and angular specifications (i.e. direction or angle between figure and ground) (Diessel 2014). Levinson $(1996$; 2003) adds a viewer or a viewpoint that must not be identical with the origin of the frame of reference. He establishes an alternative typology of frames including three different types, i.e. the relative frame of reference, the intrinsic frame of reference, and the absolute frame of reference. Definitory feature are the number of arguments involved and their alternating properties. Spatial adpositions form part of the argument structure and therefore count for the number of arguments. In the following I will refer to spatial deixis considering the location of figures within a spatial frame and how 
spatial adposition are grammatically involved to express their relations. Adamawa languages tend to express space with structures involving referential markers like adpositions or other deictic expressions (Littig forthcoming). The general questions of the survey are presented in the following section.

\section{The survey}

Based on the definitions presented above I question what kind of adpositions the individual language has according to their function (i.e. spatial, temporal, semantic etc.) and form (i.e. phonology, morphology, position etc.). I also consider if there is a generic adposition that functions to express spatiality in general. If a language has such an adposition I discuss its forms, positions, and variants. I describe if adpositions are part of spatial expressions (in, on, at, above etc.). I will show whether there are formal similarities (i.e. phonological, morphological, position) all over the Adamawa language group. The survey starts with Longuda, the Bua languages, Mumuye and Kebi Benue and closes with the Samba Duru Group. An overview of the survey languages (and their sources) sorted after language subgroups is presented in Table 1.

Table 1

The survey languages

\begin{tabular}{|c|c|c|c|c|c|}
\hline Samba Duru & Kebi-Benue & Mumuye & Bua & Longuda & Fali \\
\hline Kolbila & Mundang & Zing dialect & Lwàa & Deele & Boulgou Fali \\
\hline Samba Leeko & Nganha Mbum & & & Guyuk & \\
\hline Dii & & & & & \\
\hline Pere & & & & & \\
\hline Doyayo & & & & & \\
\hline Beiya & & & & & \\
\hline Riitime & & & & & \\
\hline
\end{tabular}




\subsection{Longuda}

According to Vigeland (forthcoming) the five dialects Cerin, Deele, Guyuk, Gwaanda and Kola, spoken in the north-east of Nigeria, form the Longuda language cluster that is classified as a separate group within the Adamawa languages. I rely on Vigeland's yet unpublished data for the Deele and Guyuk variants. A preposition á expresses spatial relations in general. $a$ precedes the noun it relates to. Specific deictic frames involving a position specifying expression (i.e. in, on, above etc.) form a circumposition around the head noun. This can be observed in Fali (see §2.5.) and in Beiya (see §2.6.6) too, as will be presented below.

(1) Deele (Vigeland forthcoming)

á tí-ká sákíỳ̀

PREP tree-CL behind

'behind the tree'

(2) Guyuk (Vigeland forthcoming)

á zí-ká yôw

PREP town-CL inside

'in(side) the town'

\subsection{Bua languages}

Boyeldieu et al. (2020) refer to 14 languages (3 extinct) forming the Bua group spoken in Southern Chad. In their paper they refer to the noun class system of Kulaal representing the group and reconstruct a class *-U_ku including body parts and places. In Boyeldieu et al. (2018) they refer to "gender $k \grave{u} / t \grave{v}$ [that] contains four terms, the behaviour of which looks more or less irregular" covering the expressions Pseudocedrela kotschyi (tree), mouth, millet, village (urban area). In general, there is no data for spatial constructions for the Bua group yet ${ }^{1}$, but Boyeldieu

${ }^{1}$ In Boyeldieu et al. (2018) we find the Kulaal expression fă $\underset{\sim}{n}$ for 'west'. 
$(1985)^{2}$ gives an appendix with a story in Lwàa, of which I extracted some possible spatial constructions.
(3) a. jì̄n
tàrm
sāá:l
wàn $\quad n \grave{e}$
1 SG.E
want.IND
go.vN
chief at/to
'Me [I] want to go to the chief.' (Boyeldieu 1985: 409)
b. ì̀ mál nè
3PL put there
'They put [it] there.' (Boyeldieu 1985: 411)

In both examples (3a) and (3b) there is a postposed element nè, translated as at/to (in French: chez) and there (in French: là-bas) by Boyeldieu (1985). In Boyeldieu's paper on personal pronouns I examined two examples mentioning the spatial expression dāàn (middle).

(4)
a. $\dot{r} \quad t i$
$t \bar{r} \quad \dot{r}$
làg
$\grave{r}$
súl dāàn

3sG.s stay.IND 3sG.s look_at.IND LoGs.poss head middle 'He stayed (and) thought about (lit. looked at his own head).'

b.á wò bür tĩ à dāàn lín [...]

3PL.S PROG ask at LOGS.POSS middle thus

'They were asking among themselves (lit. in the centre of themselves) thus...' (Boyeldieu 2020)

\subsection{Mumuye}

Mumuye forms a dialect cluster that is spoken in Gongola state, Northeastern Nigeria. Shimizu (1979) mentions at least fifteen dialects of Mumuye. I focus on the Zing dialect of the Zing group as presented in Shimizu (1979; 1983). Zing is spoken in the town of Zing (Zinna) and some adjacent settlements (Shimizu 1979; 1983). The dialect has prepositions and postpositions. There is a preposition á expressing

${ }^{2}$ I translated the examples and revised the gloss in accordance with the Leipzig Glossing rules. 
general spatial relations and a postposition $n i$, referring to spatial containment (in). In example (5) the use of both adpositions is presented.

$\begin{array}{lllllll}\text { (5) } 6 e \grave{e ̀} & a ́ & m o ̀ & \text { shoo } & n i & 6 a & y a \\ \text { DEM.PL } & \text { PREP } & \text { 2SG.POSS } & \text { ear } & \text { in } & \text { NEG } & \text { Q }\end{array}$

'Aren't these in your ear?' (Shimizu 1983: 138)

The preposition á takes part in spatial expressions, as example (5) shows.

\subsection{Kebi-Benue}

The Kebi-Benue group, named after the rivers Mayo Kebi and Benue, forms a language group of Adamawa and is identical to Greenberg's Adamawa 6 and Boyd's Mbum or Lakka group. The group includes about 20 languages spoken in Cameroon, Chad and the Central African Republic (Elders 2006). For the survey I included Mundang (Elders 2000) and Mbum of Nghanha (Hagège 1970a; 1970b) and Mbum of Mbang Mboum (Hino 1978) spoken in the region of Ngaoundéré, Adamawa Region of Cameroon.

\subsubsection{Mundang}

Elders (2000) describes a preposition kà expressing spatial and temporal relations. He glosses the preposition in French $a$. The preposition occurs in sentences with body parts, spatial nouns or spatial adverbs as presented in the examples. ${ }^{3}$

(6) málán hỉé bĩ girl DEM deliver PREP house

'This girl gave birth at home' (Elders 2000: 243)

${ }^{3}$ I translated the examples given originally in French to English and modified the glosses. 


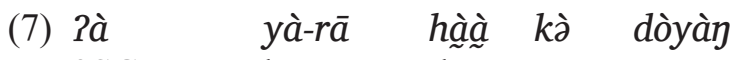

3SG..IPFV be.VN-PL there PREP Doyang

'They live in Doyang'. (Elders 2000: 243)

(8) pááá nò kà nán 6ò

herbs COP.LOC PREP eye 2SG.POSS

'There are herbs in your eye'. [Don't gossip.] (Elders 2000: 243)

In (6) and (7) the preposition precedes the place of the action described in the sentences. In (8), a proverb, the preposition relates to a body part and interacts with a copula nò that Elders (2000: 292ff.) calls "copule locatif-existentiel", a copula expressing universal locative existence. If the copula is combined with kà (or other prepositions), it bears a locative meaning. kà does not specify the spatial reference frame (Elders 2000: 254), but takes part in constructions involving the locative copula as pointed out in (9).

\section{(9) nò kò lílì \\ COP.LOC PREP outside \\ 'It's outside.' (Elders 2000: 293)}

In summary the adposition kà functions as a general modifier used with a specific spatial expression and as a usual preposition with general spatial meaning that does not require additional information on spatiality.

\subsubsection{Nghana Mbum and Mbang Mbum}

The data provided in Hagège (1970a; 1970b) is not satisfying. The author relates to a specific structuralist theory, according to which he provides and classifies his data. Adpositions are grouped under the labels "fonctionnels" or "indicateurs de function" (Hagège 1970a: 117). There is no spatial adposition that expresses spatial relations in general or no data is provided for such an adposition. I highly doubt the lack of a general adposition as all other languages show such an adposition. He presents a form à that he translates as French de (Hagège 1970a: 115) but $\grave{a}$ is not analyzed as an adposition. He does not clarify if he 
considers $\grave{a}$ as a preposition with no function in a sentence or a relator between two words like the French preposition de. A deictic meaning is not excluded. He only shows, in comparison with the preposition bi (translated as French dans 'in'), how à cannot be combined with a deictic expression (Hagège 1970a: 116). à is not categorized at all and there are not enough examples given, so that I could not analyze the function of $\grave{a}$ myself. Therefore, I could not decide whether $\grave{a}$ has a spatial function or not. He lists several elements including the spatial expressions bí "dans" ('in'), dìgà "depuis, de" ('from, since'), há "jusqu'à" ('until, to'), kàbí "par l'intérieur de" ('from the inside'), hábí "jusqu'à l'intérieur de" ('to the inside'), ngêr "sur" ('on'), tibà "sous" ('under, beneath'), fôl "devant ('before, in front of'), bêl "à côté de" ('beside, next to'), bíl "à l'inértieur de" ('at the inside') (Hagège 1970a: 116). The expressions are combined or show a consonantal ending $(-l)$ that might be a spatial marker. There are no further examples presenting the use or the function of these elements. There is only one example that shows the position of bi that is preposed, see example (10). I therefore assume that the other so called "indicateurs de function" are prepositions too. The demonstrative ài might consists of the element $\grave{a}$ and a referential marker $i$ but as there are no contrastive examples provided, I cannot validate this assumption.

\section{(10) gûn ài bí pàk pàn \\ child DEM in hut be_still \\ 'This child is (still) in the hut'. (Hagège 1970a: 116)}

In Hagège (1970b: 301) examples for the use of bi as a rather general spatial preposition in a generic function are given, see (11a, c). The author also shows that $b i$ is facultative, as it easily can be dropped without changing the meaning $(11 \mathrm{~b}, \mathrm{~d})$.

(11) a. bí làù pàk

in middle hut

'in the middle of the hut' 

b. làù pàk
middle hut
'in the middle of the hut'
c. bí nzák mbì
in river bank
'at the river bank'
d. nzák mbì
river bank
'at the river bank' (Hagège 1970b: 301)

The lack of data and the poorly explained examples prevent a detailed analysis at this point. Even in comparison with the Mbum variant of Mbang Hagège's assumptions are doubtful. Hino (1978) mainly presents spatial expression either in combination with bí or with $\grave{a}$ and not isolated (Hino 1978: 335ff.).

\subsection{Fali}

Within the Adamawa language group Fali is nowadays classified as an isolate (Kleinewillinghöfer 2019). It is spoken in the North Region of Cameroon in an area from Garoua in the South to Dourbeye and Bossoum up North (Kramer 2014). I will concentrate on the data of the Fali of Boulgou. Analogous to Mundang, Fali shows mainly prepositions (there is one circumposition, expressing directionality ${ }^{4}$ ). Kramer (2014) describes three primary adpositions and eight secondary adpositions. There is one adposition $\grave{b}$ expressing spatial relations and occurs within a prepositional phrase as in example $(12)^{5}$ (Kramer 2014: 176ff.).

${ }^{4}$ The circumposition tò...wò is listed in the overview of all adpositions in Fali (Kramer 2014: 176), but not further explained in the following, there are no examples given for its use and no assumptions if it is formed by a combination of the postposition $\grave{p}$, which might be considering its phonological form.

${ }^{5}$ The examples are translated from German to English and slightly modified according to the Leipzig Glossing rules. 


\section{(12) ee na:-si $\quad p \quad$ gopri \\ as climb-PLA PREP hill CCG}

'As he climbed up the hill again.' (Kramer 2014: 176)

$\grave{D}$ expresses spatiality in general and takes part in secondary adpositions specifying deictic reference. Kramer (2014: 181ff.) analyzes them as presented in the following:

(13) ìdát 'behind, after' < PREP ì + da:ti 'back'

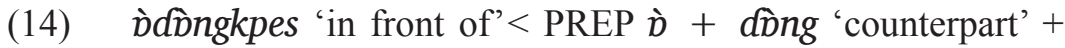
kpe:si 'face'

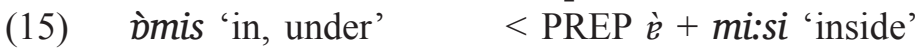

(16) ìfák 'on' < PREP ̀̀ + faw 'heaven'

(17) D̀gin 'to' < PREP ̀̀ + gini 'place'

(18) ìndèr 'in' < PREP ̀̀ + nder 'in'

(19) b̀lès 'under' < PREP ì + les 'under'

$\grave{p}$ is combined with a noun (or even a compound as in example (14)) forming a prepositional construction with a general spatial adposition and a grammaticalized specific adposition. Examples (18) and (19) are combinations with loanwords of Fulfulde. The set presented above proves the general function of $\grave{D}$ in Fali.

\subsection{Samba Duru}

Samba Duru is a branch of Central Adamawa and consists of four branches: Vere Gimme, Doyayo, Duru and Samba (Kleinewillinghöfer 2019). In Table 2, the overview of the Samba Duru Branch, as presented on the Adamawa Language website (Kleinewillinghöfer 2019), is given. The languages that will be further discussed within this survey are underlined.

Kolbila and Samba Leeko belong to the Samba Branch of Samba Duru. Kolbila is spoken by less than 6000 speakers in Northern Cameroon along the main route from Ngaoundéré to Garoua, in the mountains near and around the city of Poli in the canton of Bantadje. 
Table 2

\section{Samba-Duru language groups}

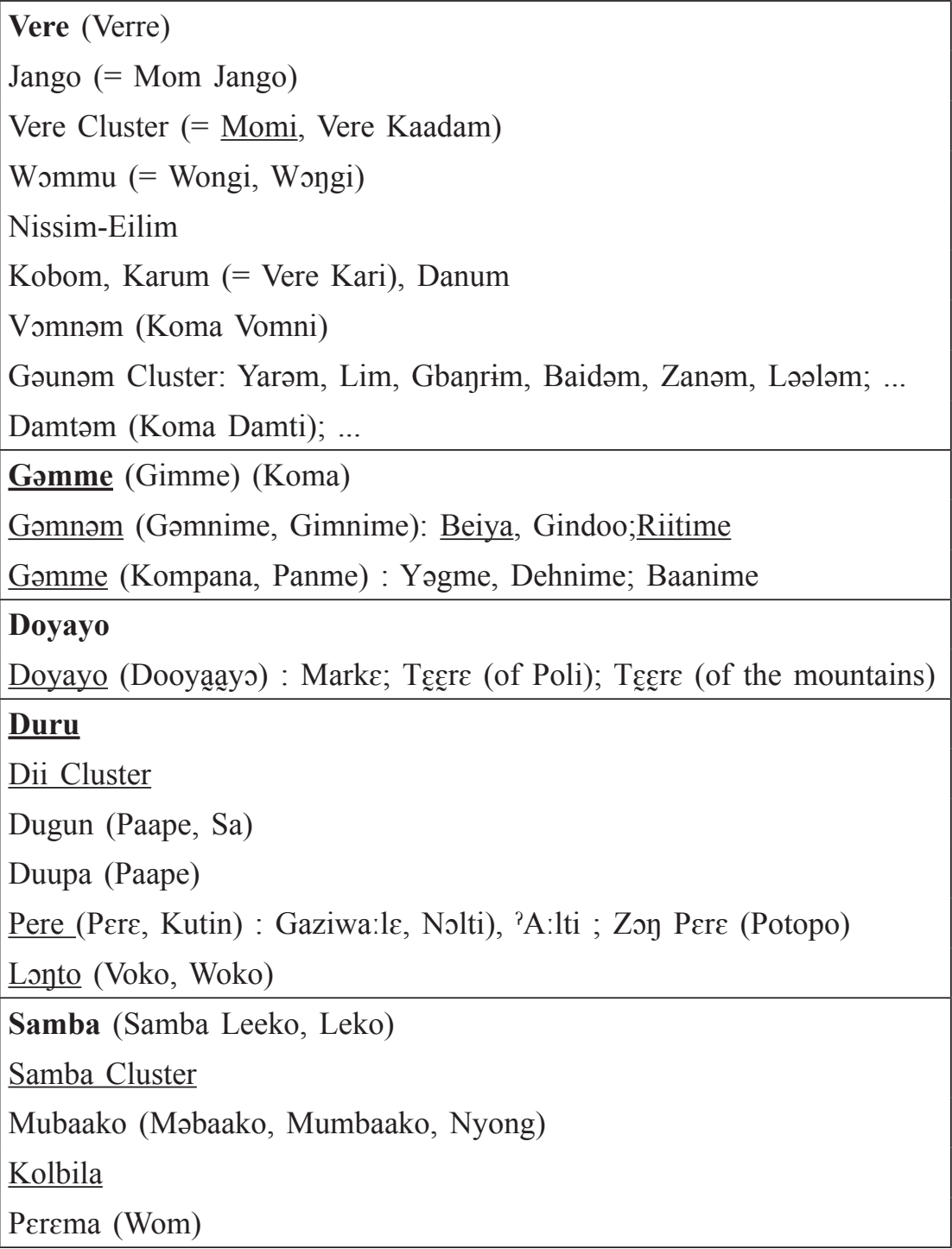


Samba Leeko is spoken in the North of Cameroon and in Nigerian in the Eastern region of the Alantika Mountains (Fabre 2003).

Kleinewillinghöfer (2019) considers Doyayo as a dialect cluster consisting of Marke; the dialect of Poli (Teqre) and the Teqre dialect of the mountains around the city of Poli (Faro district) the dialect cluster forms its own branch within the Samba-Duru group. There are an estimated number of 18,000 native speakers (Wiering \& Wiering 1994).

Pere and Dii belong to the Duru branch of Samba Duru. Dii or Duru is spoken in the Northern Region and Adamawa Region of Cameroon, mainly in Mayo-Rey Division, Tchollire Subdivision, Vina Division, Ngaoundéré Subdivision and the North and East of Ngoundere along the Main Route in direction to Garoua (Bonhoff 2014). With estimated 20,000 speakers, Pere is situated in the Adamawa Region of Cameroon in the Northwestern region of Tignère (Kastenholz 2011).

According to Kleinewillinghöfer (2019), the Gəmnəm subgroup of the Gəmme Branch of Samba Duru is presented by Beiya and the close related Riitime. Beiya and its Nigerian variant Gindoo are spoken in the southern part of the Alantika Mountains and the adjacent foothills and plains in Cameroon (Northern Region) and Nigeria (Adamawa State) from Wangay (Cameroon) to Tantile (Nigeria). There are an estimated 39,000 speakers for Beiya. Riitime is mainly spoken in Ndingtere and its region at the foot of the Alantika Mountains close to the Faro River.

\subsubsection{Kolbila}

Kolbila has a postposed adposition expressing spatial relations in general. The postposition can be clitizised to a noun ((20), (21) and (25)) or it occurs as a free form bú ((22), (23) and (24)).

(20) ārkéēn yāā yīl=ú

woman come house $=$ POST

'A woman comes to the house.' (Littig, fieldnotes) 
(21) $m \bar{a}$ zá $\quad y \bar{l} l=u ́$

$1 \mathrm{PL}$ leave house $=$ POST

We leave the house.' (Littig, fieldnotes)

(22) nābsé dá tábàlà bú

cat be table posT

'The cat is on the table.' (Littig, fieldnotes)

(23) ārkéēn-à dōd tábàlà bú

woman-DIM sit table POST

'The girl sits at the table.' (Littig, fieldnotes)

(24) mú dì nēd jạáád bú

2SG go hand left POST

'You go to the left.' (Littig, fieldnotes)

(25) wàà àrváān-à dīi $\emptyset$ dá bās tól $\quad$ bú bēáll=ú

child male-DIM stand 3sG be fence environment POST up=POST

'The boy stands (upwards), he is next to the fence.' (Littig, fieldnotes)

The examples above underline the generality of the adposition in regard to spatial deixis. Examples (20), (21) and (24) show that the adposition is neutral in relation to direction. In (20) and (21), coming to the house and leaving the house are equally marked by the adposition clitized to the noun yil (house). In example (24), the adposition takes part in the complex expression of 'left' and indicates a direction too. In examples (22) and (23), the adposition is even neutral in position. Being on the table and sitting at the table is expressed in the same way. Example (25) is a complex structure with an embedded clause (underlined). The postposed compound $b \bar{\varepsilon} a ́ l l=u$, a spatial expression, consisting of a noun and the adposition $u$, describes the manner of the action of the boy (to be upright). In general, the adposition is part of complex spatial expressions indicating contact, adhesion and containment (e.g. 'in', 'above', 'behind', 'under', 'on', 'in front of' etc.) as seen in example (25) and the following examples. 


\section{(26) kòpsè dá gbóm $\quad p \bar{e} e \bar{r} r=u ́$ \\ crocodile be monkey behind=POST}

'The crocodile is behind the monkey.' (Littig, fieldnotes)

(27) bàsè dá bĩ núm=ú

frog be stone front=PosT

'The frog is behind the stone.' (Littig, fieldnotes)

According to their function I analyze the postposed spatial expressions as secondary adpositions in terms of Hopper \& Traugott (2003). As the examples show they describe the position of the subject in relation to a noun and are always postposed (and even follow the general postposition, see example (25)).

\subsubsection{Samba Leeko}

Fabre (2003: 94ff.) describes a postposition dú similar to Kolbila's postposition ú. The postposition shows different variants. In final position following a consonant it is realized as [ú]. In internal position following a consonant it is [á]. Following a vowel in final position it is realized as [rú] and following a vowel in internal position it is realized as [ró] (Fabre 2003: 94ff.). In the appendix to (Fabre 2003) I found examples of the postposition directly cliticized to the noun (28) or in complex spatial expressions as in example (30).

(28) sée $\varnothing$ záa pì fàg $=$ ú

so 3sG get_up enter wild=POST

'So he gets up and enters to the wild.' (Fabre 2003: 380)

(29) $\emptyset \quad$ kùm nāgàl yúl bā wa=rò ní $3 \mathrm{SG}$ sit grinder head on there $=$ POST just

'He just sits in front of the grinder.' (Fabre 2003: 384)

(30) Tên ?èmà núm =ú

first walk in front $=$ POST

'The first one walks ahead.' (Fabre 2003: 384)

${ }^{6}$ The examples are taken out of Fabre 2003 and translated to English. The glosses are modified according to my own analysis. 


\subsubsection{Dii}

Bonhoff (2014: 150) refers to a suffix -lt that bears the function of a spatial adposition like in the other languages presented above. I question the analysis as a suffix. It is not restricted to a specific part of speech, as presented in the examples. It bounds with nouns (31), demonstratives (33), determiner (34), names (36), verbs (35), and pronouns (37). Therefore, I would prefer to analyze it as a bounded adposition rather than a suffix.

(31) à̀m làà $k a a=l e ́ \quad s a ́$

3SG.INJ go village=POST MP.INJ.NEG

'Don't go to the village.' (Bonhoff \& Boyd 2003: 8)

(32) bà?á $\varnothing \quad d \dot{t} \quad k a a=l \dot{t}$

dad $3 \mathrm{sg}$ be village $=$ POST

'Dad is in the village.' (Bonhoff \& Boyd 2003: 14)

(33) hág á yغ̀=lt́

ground on $\mathrm{DEM}=\mathrm{POST}$

'Here on the ground.' (Bonhoff 2010: 188)

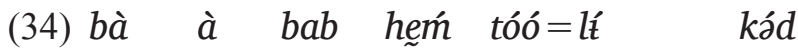

plant 3SG field place a_certain $=$ POST different

'He plants a field at a different place.' (Bonhoff 2014: 97)

(35) bad yá?í=lí

mud dig=POST

'In digging in the mud.' (Bonhoff 2010: 185)

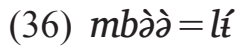

Mbé $=$ POST

'In Mbé.' (Bonhoff 2010: 185)

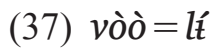

3PL.at=POST

'At their's (At their house).' (Bonhoff 2010: 185)

I could extract several spatial expressions (e.g. àwult 'there', ka?z 'next to', koogí 'behind', nagí 'in hand') consisting of one part of speech (i.e. demonstrative or noun) and the element $l \dot{t}$ (Bonhoff 2014). 
The examples and the spatial expression suggest that $l \underline{t}$ is an adposition, which functions as a general marker of spatiality analogous to the adpositions ú of Kolbila and dú of Samba Leeko.

\subsubsection{Pere}

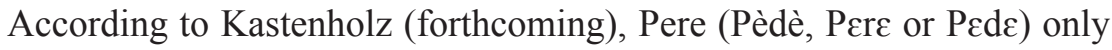
has postpositions. There is a free form $t \bar{t}$ expressing spatial relations in general (examples (38) and (39)).

(38) bālé:, wà̀l dá: tī, yíd gá pém tà-̄̄ gím before village one POST person FOC all see-IPFV misery

'Once upon a time in a village, all the folks were living in misery.' (Kastenholz, fieldnotes)

(39) wà̀l zèy tò tì pém, vā kì̀- $\bar{\eta}$

village backside PL POST all 3PL hear-IPFV

vādám $y \bar{a} g \quad$ bá:-dì

cild.PL mouth cry-VN

'Behind any of the villages, one could hear [the voice of] children crying' (Kastenholz, fieldnotes)

In spatial deictic expressions it follows a head noun within a genitive construction (example 40). Example (40) specifies the direction (ahead, in front of). $t \bar{t}$ is obligatory in these complex deictic expressions.

(40) nén tī
front POST
'in front of'

\subsubsection{Doyayo}

Doyayo has two postpositions marking spatiality in general. The clitizised $l \bar{\varepsilon}$ that is phonological bound and the free form dú. The language also shows a preposition á indicating direction. In example (41) $a$ is translated as 'at' by Wiering \& Wiering (1994) but expresses directionality. The postposition dú is translated as 'in'. Considering 
sentence (42) the translation from dú to 'in' makes no sense at all, as there is no containment expressed. I therefore prefer to analyze it as a general spatial marker. The case of $a$ is similar confusing as it is used in (41) to express directionality but translated as 'at'. à precedes the place it relates to, whereas $l \bar{\varepsilon}$ and $d \dot{u}$ are postposed. The adpositions are not described by the authors in detail.

(41) $\check{i s} \quad \emptyset \quad w \bar{\varepsilon} \bar{\varepsilon} \quad$ a $\quad g i ́ \quad l \varepsilon^{\prime}=l \bar{\varepsilon}$ goat $3 \mathrm{SG}$ returned DIR $3 \mathrm{SG} . \mathrm{POSS}$ place $=\mathrm{POST}$

'The goat went home (to her place).' (Wiering \& Wiering 1994: 203)

(42) mó yếl dú

2sG.POSS back POST

'On your back.' (Wiering \& Wiering 1994: 204)

\subsubsection{Beiya}

Beiya is one of the class languages within the Samba Duru family. It has 10 noun classes. It has no locative class as such but a k-class containing nouns like 'place', 'mountain', or 'room' (Kleinewillinghöfer forthcoming; Dieu \& Perrois 2016). In Beiya a postposed adposition Cō marks general spatial relations. The postposition is combined with a preceding consonant $(\mathrm{r} / \mathrm{p} / \mathrm{l} /$ other $) .{ }^{7}$ Within the noun phrase the adposition $C \bar{\partial}$ follows the noun it relates to and is phonologically bound as shown in the examples (43) to (46).

(43) $m i ̄$ ỳ̀̀̀ mīn $\quad r \bar{a}-\grave{a}=<r>\bar{\partial}$

$1 \mathrm{SG}$ be $1 \mathrm{SG} . \mathrm{POSS}$ house- $\mathrm{CL}=<\mathrm{C}>$ POST

'I am in my house.' (Littig, fieldnotes)

(44) wáá yò̀ tèè ${ }^{2}=<p>\bar{\partial}$

child be wood $=<\mathrm{C}>$ POST

'The child is on the table.' (Littig, fieldnotes)

${ }^{7}$ Currently I neither have a satisfying explanation for the choice of the preceding consonant nor the question if it is an element of the noun or the postposition. 
In the following example a complex spatial deictic construction is represented involving a source and a direction (goal). The direction is marked by another adposition $s \bar{\partial}$ in combination with $\bar{\partial}$ forming a circumposition, comparable with the circumposition Kramer (2014) mentions for Fali (section 2.5) and the structure of the Longuda adpositions (section 2.1).

$$
\begin{aligned}
& \text { ?ūū wát } r \bar{a}-\grave{a}=<r>\bar{\partial} \quad \text { sā } \quad g b i \grave{\imath}-l=<l>\bar{\partial} \\
& 1 \mathrm{P} \text { go house- } \mathrm{CL}=<\mathrm{C}>\mathrm{POST} \text { DIR river- } \mathrm{CL}=<\mathrm{C}>\mathrm{POST} \\
& \text { 'We go from (the) house to (the) river.' (Littig, fieldnotes) }
\end{aligned}
$$

There are some spatial expressions that contain the adposition (see Table 3). Some free forms that function as spatial postpositions specify spatial deixis (on, under etc.) do not contain the adposition $\bar{\partial}$. In structures expressing spatial relations like example (46) the spatial adposition precedes the specifying expression.

$$
\begin{aligned}
& \text { (46) } t \bar{e} e^{2}=<p>\bar{\partial} \text { dī } \\
& \text { tree }=<\mathrm{C}>\text { POST under } \\
& \text { 'Under the tree' (Littig, fieldnotes) }
\end{aligned}
$$

In Table 3 I list the specific spatial expressions that are recorded so far (Kleinewillinghöfer forthcoming; Littig forthcoming) and mark if they contain the spatial adposition or not. Out of eight expressions half is formed of a combination with $C \bar{\partial}$. The expressions that are not combined with $C \bar{\partial}$ take at least part in a structure involving the adposition $C \bar{\partial}$ as presented in (46).

\subsubsection{Riitime}

Riitime is a noun class language with 10 differing nouns classes including K-classes like Beiya. (Kleinewillinghöfer forthcoming). The language has an adposition $O$ that is phonologically bound. It causes a gemination of the final consonant and is sensitive to tonal changes according to the preceding tones as shown in the examples. 
Table 3

Beiya spatial expressions

\begin{tabular}{|c|c|c|}
\hline Specific spatial expression & Meaning & $C \bar{a}$ \\
\hline $\bar{a}-k \bar{a}$ & 'close to' & yes \\
\hline$r o^{?}$ & 'in' & no \\
\hline gá-lā & 'outside' & yes \\
\hline$b \dot{\varepsilon}-k \bar{\partial}-p$ & 'next to' & yes \\
\hline$m \bar{t} \eta g \grave{t}-b \bar{\partial}$ & 'in front of' & yes \\
\hline$d i ̄ i ̀$ & 'under' & no \\
\hline pàā & 'on' & no \\
\hline pàāí & 'above' & no \\
\hline
\end{tabular}

(47) $y a \bar{k}$ yò̀̀ $d u ́-l=l o ́$

cat be hole-CL $=$ POST

'A cat is in the hole.' (Littig, fieldnotes)

(48) yírí-wàà-bīrí $\quad \bar{a} \quad$ wūń $\quad r a \bar{a} \quad n \bar{t}-\eta=g o ̀$

human-child-male DEM 3sG.POSS house front-CL=POST

'This man is in front of his house.' (Littig, fieldnotes)

Spatial expressions e.g. $n \bar{t}-\eta \eta g=$ 'in front of', see example (48) are combined with the postposition $o$ and part of the k-class.

\section{Conclusion}

The empirical comparative study presented here was based on the following questions:

1. What kind of adpositions does the language have?

2. Is there an adposition expressing spatiality in general?

3. If yes what form, position and variants does it have?

4. Do these adpositions take part in spatial expressions ('in', 'on', 'at', 'above' etc.)?

5. Are there formal similarities all over the Adamawa language group or in specific subgroups? 
The results for questions 1 to 4 are summed up in the following tables. Table 4 presents the Samba Duru languages. In Table 5 the remaining languages are shown. The results presented in the table and the questions will be discussed in the course of the following summary.

Table 4

The survey's results for Samba Duru

\begin{tabular}{|c|c|c|c|c|c|c|}
\hline \multicolumn{7}{|c|}{ Samba Duru } \\
\hline Samba & & Duru & & Doyayo & Gəmme & \\
\hline Kolbila & $\begin{array}{l}\text { Samba } \\
\text { Leko }\end{array}$ & Dii & Pere & & Beiya & Riitime \\
\hline 1. Post & Prep, Cir, Post & ? (Post) & Post & Prep, Post & Post, Cir & Post \\
\hline 2. yes & yes & yes & yes & yes & yes & yes \\
\hline 3. ú & $d u ́$ & lé & $t i$ & $a ́, l \bar{\varepsilon}, d u ́$ & $\bar{e} / \bar{\partial}$ & $\bar{o} /-\bar{o}$ \\
\hline 4. yes & yes & yes & yes & yes & yes & yes \\
\hline
\end{tabular}

Table 5. The survey's results for Fali, Kebi-Benue, Bua and Mumuye

\begin{tabular}{|c|c|c|c|c|c|}
\hline Longuda & Fali & Kebi-Ben & & Bua & Mumuye \\
\hline Guyuk, Deele & Fali of & Mundang & Nganha Mbum & Lwàa & Zing Dialect \\
\hline 1. Prep, Cir & Prep, Cir & Prep & Prep & Post & Prep, Post \\
\hline 2. yes & yes & yes & ? & ? & yes \\
\hline 3. $a$ & $\grave{b}$ & kà & $\grave{a}, b i$ & $n \grave{e}$ & $a ́, n i$ \\
\hline 4. yes & yes & yes & ? & $?$ & ? \\
\hline
\end{tabular}

As summarized in Table 4 the Samba Duru languages mainly show postpositions. For Samba Leeko there are prepositions and circumpositions mentioned too. Doyayo has prepositions and postpositions which can be combined to express specific spatial relations. All languages have one adposition expressing spatiality in general. The adposition occurs in different phonological forms throughout the language group. It can be phonologically bound or appear as a free form. In most languages it occurs as a free form or bounded clitic as 
well. In general, the adpositions takes part in spatial expressions, either as a part within the construction (i.e. Pere) or forming a compound (i.e. Kolbila). The phonological forms vary throughout the group, there is no common form across the languages. The Gəmme languages slightly differ in the phonological form of their adposition from the whole group and to each other. This is surprising, as they are close related variants. Kolbila, Samba Leeko and Doyayo show a similar spatial adposition $(d / r-) u$ although Doyayo is special in the sense that it shows three different adpositions. Due to the lack of data the results for the remaining languages (besides Mundang and Fali) cannot be analyzed as complete as the languages of the Samba Duru group. Especially for the question of whether the spatial adpositions take part in expressions for specific spatial relations could not be answered in detail. Fali and Kebi Benue languages all show prepositions but Fali has one circumposition, similar to Doyayo or Samba Leeko. Lwàa of the Bua-Group has postpositions. Mumuye shows a preposition and postpositions as well, spatial expressions are postposed as well. A clear result of this micro-survey is that all languages have an adposition expressing spatial relations in general. These adpositions vary in form and position. The position cannot be predicted by word order as shown in the examples for the Samba Duru group. All languages have SVO word order but the adpositions are postposed.

\section{Acknowledgements}

I would like to express my gratitude to the Kolbila speakers I was honoured to work with, especially Laikossa and his family as well as the speakers of Beiya and Riitime. I'm greatful to all the participants of the 1st Adamawa Conference who shared their data and had comments to my paper and recent work in Adamawa and made the conference as pleasant as it was. I would also like to thank Ulrich Kleinewillinghöfer for his support in all questions of topics of Adamawa languages and fieldwork. Thanks to my collegue and friend Friederike Vigeland for organizing this event together with me and for her advice concerning this paper. Thanks to the reviewer and their comments on 
several versions of this paper. I am also grateful to Raimund Kastenholz who kindly provided his corpus of unpublished Pere data for the aims of this article.

\section{Abbreviations}

1 - first person

2 - second person

3 - third person

$\mathrm{C}$ - consonant

$\mathrm{CCG}$ - change of common ground

CIR - circumposition

CL - class marker

COP - copula

DEM - demonstrative

DIM - diminutive

DIR - direction

E - emphatic

FOC - Focus marker

IND - indicative

INJ - injunctive

IPFV — imperfective
LOC - locative

LOGS - logophoric singular

LOGP - logophoric plural

MP - marker of proposition

NEG - negation marker

POss - possessive

POST - postposition

PREP - preposition

PL - plural

PLA - pluractional

PROG - progressive

$\mathrm{Q}$ - question marker

QUOT - quotative

$\mathrm{s}$ - subject

SG - singular

$\mathrm{VN}$ - verbal noun

\section{References}

Bonhoff, Lee E. 2010. Some personal notes on structures in Dii. Phonology, grammar, and discourse. Ngaoundéré: Dii Literature Team.

Bonhoff, Lee E. 2014. Dictionnaire de la langue dii (duru). $4^{\mathrm{me}}$ edition. Mbé: Centre de Littérature Mbé.

Bonhoff, Lee E. \& Boyd, Raymond. 2003. Les marqueurs de proposition en langue dii (yag dii). Journal of African languages and linguistics 24(1). $1-29$.

Boyd, Raymond. 1974. Etude comparative dans le groupe Adamawa. Paris:

CNRS. (Société d'études linguistiques et anthropologiques de France 46.)

Boyeldieu, Pascal. 1985. La langue lua ('niellim'). Groupe boua - Moyen chari, Tchad. Phonologie - Morphologie - Dérivation Verbale. Cambridge: Cambridge University Press. 
Boyeldieu, Pascal. 2020. Personal pronouns in Bua languages. Language in Africa 1(3). 292-335. (This issue.)

Boyeldieu, Pascal \& Kastenholz, Raimund \& Kleinewillinghöfer Ulrich \& Lionnet, Florian. 2018. The Bua Group languages (Chad, Adamawa 13): A comparative perspective. In Kramer, Raija \& Kießling, Roland (eds.), Current approaches to Adamawa and Gur languages, 53-126. Cologne: Rüdiger Köppe Verlag.

Boyeldieu, Pascal \& Kastenholz, Raimund \& Kleinewillinghöfer Ulrich \& Lionnet, Florian. 2020. The Bua group noun class system: Looking for a historical interpretation. Language in Africa 1(3). 181-215. (This issue.)

DeLancey, Scott. 2005. Adpositions as a non-universal category. In Frajzyngier, Zygmunt \& Hodges, Adam \& Rood, David S. (eds.), Linguistic diversity and language theories, 185-202. Amsterdam: John Benjamins.

Dieu, Michel \& Perrois, Louis (avec la collaboration d'Henry Tourneux). 2016. Dictionnaire encyclopédique koma gímbē / français (Monts Alantika, Nord-Cameroun). Naples: Università degli studi de Napoli "L'Orientale". (Studi Africanistici: Serie Ciado-Sudanese 8.)

Diessel, Holger. 2014. Demonstratives, frames of reference, and semantic universals of space. Language and Linguistics Compass 8(3). 1-17.

Dryer, Matthew S. 2013. Order of adposition and noun phrase. In Dryer, Matthew S. \& Haspelmath, Martin (eds.), The World atlas of language structures online. Leipzig: Max Planck Institute for Evolutionary Anthropology. http://wals.info/chapter/85 (accessed on 2020-01-20).

Elders, Stefan. 2000. Grammaire Mundang. Leiden: CNWS Publications.

Elders, Stefan. 2006. Issues in comparative Kebi-Benue (Adamawa). Africana Linguistica 12. 37-88.

Fabre, Anne Gwenaëlle. 2003. Étude du Samba Leko, parler d'Allani (Cameroun du Nord, Famille Adamawa). Munich: Lincom. (LINCOM Studies in African Linguistics 65.)

Fillmore, Charles J. 1982. Towards a descriptive framework for spatial deixis. In Jarvella Robert J. \& Klein, Wolfgang. (eds.), Speech, place and action: Studies in deixis and related topics, 31-59. Chichester: John Wiley.

Hagège, Claude. 1970a. La langue Mbum de Nganha (Cameroun). Phonologie-Grammaire. I. Paris: SELAF.

Hagège, Claude. 1970b. La langue Mbum de Nganha (Cameroun). Phonologie-Grammaire. II. Paris: SELAF. 
Hagège, Claude. 2001. Les processus de grammaticalisation. In Haspelmath, Martin \& König, Ekkehard \& Oesterreicher, Wulf \& Raible, Wolfgang (eds.), Language typology and language universals, Bd. 2, 1609-1623. Berlin - New York: Mouton De Gruyter.

Heine, Bernd \& Claudi, Ulrike \& Hünnemeyer, Friederike. 1991. Grammaticalization: A conceptual framework. Chicago: University of Chicago press.

Hino, Shun'ya. 1978. The classified vocabulary of the Mbum language in Mbang Mboum - With ethnograpical descriptions. Tokyo: Institute for the Study of Languages and Cultures of Asia and Africa (ILCAA).

Hopper, Paul J. \& Traugott, Elizabeth. 2003. Grammaticalization. Cambridge: Cambridge University Press.

Kastenholz, Raimund. 2011. Diachronic and synchronic aspects of a nominal suffix *-i in Pere. In Kramer, Raija \& Tröbs, Holger \& Kastenholz, Raimund (eds.), Afrikanische Sprachen im Fokus. Linguistische Beiträge zum 19. Afrikanistentag, Mainz 8.-10. April 2010, 129-142. Cologne: Rüdiger Köppe Verlag.

Kastenholz, Raimund. forthcoming. The Pere language (working title).

Kleinewillinghöfer, Ulrich. 2011. Assoziative Konstruktionen im VereGimme und Loyto, Central Adamawa. In Kramer, Raija \& Tröbs, Holger \& Kastenholz, Raimund (eds.), Afrikanische Sprachen im Fokus. Linguistische Beiträge zum 19. Afrikanistentag, Mainz 8.-10. April 2010, 143-161. Cologne: Rüdiger Köppe Verlag.

Kleinewillinghöfer, Ulrich. 2019. Adamawa language groups. https://www. blogs.uni-mainz.de/fb07-adamawa/adamawa-languages/ (accessed 202001-20)

Kleinewillinghöfer, Ulrich. 2020. Adamawa. In Vossen, Rainer \& Dimmendaal, Gerrit J. (eds.), Handbook of African languages, 220-230. Oxford: Oxford University Press.

Kleinewillinghöfer, Ulrich. forthcoming. Noun class Languages in Central Adamawa. Beiya with contributions of Iya Voozi of Maiwa. Riitime with contribution of Yongui Boni of Yemti Liwa. Kobom with contribution of Jean Hubert Djika and Madame Djika (working title).

Kramer, Raija. 2014. Die Sprache der Fali in Nordkamerun. Eine funktionale Beschreibung. Cologne: Rüdiger Köppe Verlag. 
Levinson, Stephen C. 1996. Frames of reference and Molyneux's question: crosslinguistic evidence. Bloom, Paul \& Peterson, Mary A. \& Nadel, Lynn \& Garrett, Merrill F. (eds.), Language and space, 109-169. Cambridge: MIT Press.

Levinson, Stephen. 2003. Space in language and cognition. Cambridge: Cambridge University Press.

Libert, Alan R. 2006. Ambipositions. Munich: Lincom. (Lincom studies in language typology 13.)

Littig, Sabine. 2016. Linguistische Beschreibung des Kolbila. Eine Adamawasprache der Nordregion Kameruns. Cologne: Rüdiger Köppe Verlag. Littig, Sabine. 2018. What happens to the adjective class in Samba-Duru? The expression of qualification in Kolbila, Duru and Beiya. Arbeitspapiere des Instituts für Ethnologie und Afrikastudien der Johannes Gutenberg-Universität Mainz 180.

Littig, Sabine. forthcoming. Marking space in Adamawa languages.

Reindl, Donald F. 2001. Areal effects on the preservation and genesis of Slavic postpositions. In Šarić, Ljiljana \& Reindl, Donald F. (eds.), On prepositions, 85-100. Oldenburg: Carl-von-Ossietzky University Oldenburg. (Studia Slavica Oldenburgensia 8.)

Shimizu, Kiyoshi. 1979. A comparative study of the Mumuye dialects (Nigeria). Berlin: Reimer. (Marburger Studien Zur Afrika- und Asienkunde. Serie A: Afrika 14.)

Shimizu, Kiyoshi. 1983. The Zing dialect of Mumuye: a descriptive grammar. Hamburg: Buske.

Tröbs, Holger. 1998. Funktionale Sprachbeschreibung des Jeli (WestMande). Cologne: Rüdiger Köppe Verlag. (Mande Languages and Linguistics 3.)

Vigeland, Friederike. forthcoming. A grammar of the noun in Longuda/ Nungurama (Adamawa). (working title).

Wiering, Elisabeth \& Wiering, Marinus. 1994. The Doyayo language. Selected studies. Arlington: Summer Institute of Linguistics. 